\title{
Zakah and its Utilization as Working Capital for Micro, Small and Medium Enterprises
}

\author{
Zainal Arif ${ }^{1)^{*}}$, M. Nurzansyah ${ }^{2)}$ \\ 1), 2) Islamic Banking, Faculty of Islamic Studies , University of Muhammadiyah Tangerang, Banten, Indonesia
}

\begin{abstract}
Zakah is an obligation that is directly mandated by Allah in the holy Quran. Zakah is assumed as a solution to overcome the poverty in Indonesia if it is well organized and well utilized.
\end{abstract}

The focus of this study is how to empower zakah productively by distributing zakah fund in the form of working capital to mustahik. This study uses descriptive method that is decribing the condition or facts finding with proper interpretation.

The result of the study shows that they are many zakah management agencies practice productive zakah model by distributing the working capital to mustahik so that they are able to change their social status to be muzakki. It can be concluded from this study that productive zakah by giving working capital for the micro, small and medium enterprises is an alternative way and effective effort which get them out of the poverty chain to be independent in economic matters.

Keywords:- Zakah, Working Capital, The Micro, Small And Medium Enterprises.

\section{INTRODUCTION}

Zakah is one of the most important Islamic Pillar. Its position can be seen In Quran as it is usually mentioned after shalah (Prayer). It shows a great wisdom behind. If shalah is a means of communiction to God, while zakah is a means of socialization among people. Next if zakah is well organized and the haves are aware about it, it can overcome the poverty. (Helliana, 2012)

In order to handle the poverty for national welfare, Zakah should be widely effective. In this case, its position must be an instrument to solve the poverty problem. It can be a link of tranferring money from the haves to the haves not. It is also aimed to build the fair and prosperous community order. The haves should give a part of their wealth to the haves not. So, they are not separted from their community because of their wealth and neglect their obligation to the humans. (Umar, 2008). This is in accordance to hadith that was narrated by Imam AlAsbahani from imam At-Thabrani.

In the book Al-Ausath and al-Shagir, the Messenger of Allāh said:

"Verily Allah Almighty has obliged Muslims to be obliged to pay zakat which can overcome poverty. It is not possible to happen that a poor person suffers from hunger or lack of clothing, except because of the inherent mischief in Muslim journalists. Remember, Allah SWT will do a careful calculation and ask for their accountability and then will torture them with a painful torment. "

This hadith is reminiscent of the magnitude of the contribution of harsh and stingy behavior to poverty. That human beings who are given more assets must help their neighbor in need.

Commonly, zakah is fulfilled consumtively. That is to satisfy daily need, such as : clothing, food and shelter. But, if it is considered further, this kind of consumption will rapidly fade. The mustahik will live as their previous condition since the donated money are not well invested. Hence, the term of productive zakah appears. It is a kind of an alternative solution to free mustahik from the poverty and their dependence to others help.

Productive zakah is not a similar term to zakah mal or zakah fitrah. It is only a form of zakah utilization. So, zakah distribution is more productive by giving the mustahik the working capital.(Rusli, 2013). As a basis of productive funding for social economic development, Zakah is distributed as a working capital to establish small enterprise sectors to get long term income.

With its productive distribution, zakah is aimed to motivate the mustahik to develop their business potential, to optimize the donated fund. So, it can build the economic independence and productive culture society. Based on fiscal analysis, zakah is basically a source of income and economic finance. (Bariadi, 2005). So, the target of zakah utilization is any ways that give and last the benefits for all people including small and medium enterprises. (Bariadi, 2005)

Wheteher Al-Qur'an sura At-Taubah : 6 mentions that they are 8 groups who accept zakah. But, Bahri commented (Bahri, 2013) that Zakah management agency should possess innovation on zakah utilization. This innovation is important to guarantee that collected zakah really has the benefit and long term impact. The benefit can be measured on how assisted mustahik are able to develop their position to be muzakki. This condition can be realized by giving them business capital as micro, small and medium enterprises. Based on the fact, that the role of micro, small and medium enterprises is significant in overcoming the poverty and decreasing the rate of unimployment. So, it is urgent to develop the micro, small and medium enterprises, especially the micro ones. It is a kind of strategic effort to carry out the development based on the equity. The effort of micro enterprises 
empowerment with the majority platform below five million rupiahs, is assumed as a stright step to overcome the poverty and cut the chains which cuff people. (zakat and Empowerment).

Nowadays, they are below $2 \%$ of businessmen in Indonesia. This condition makes many zakah management agencies form productive zakah as one of the pattern to empower the mustahik by giving them the working capital and training to be more creative and initiative. It is intended to increase the number of businessmen in Indonesia.

Based on previous description, the focus of this study is how productive zakah is able to be the working capital for micro, small and medium enterprises. Secondly, how far the benefit of productive zakah as a working capital for mustahik.

\section{THEORETICAL BASIS}

\section{$>$ Productive zakah}

Nowadays, productive zakah is an interesting and growing topic in zakah mangement agencies. It is because of its ability to save the haves not from the chain of poverty. As Bariadi said (Bariadi, 2005), Productive means a fund that is lent by amil to mustahik for business need. Productive program is intended to productive business with medium - long term. Commonly, The effect of this productive business still can be found eventhough the zakah fund is finished. This productive business can be classified to (community development program) and micro,small and medium enterprises .(IMZ, 2010)

The utilization category of productive zakah can be classified into two kinds. First, Traditional productive zakah. It is a kind of zakah that is given in the form of productive goods. Such as: goat,cow, sewing machine, handycraft tools, etc. This kind of zakah can support mustahik to create the certain job or it can give a new job opportunity for them. Second, creative and productive zakah. It is given to the mustahik in the form of working capital. It can be used to help the conduct social project or to help or to add someone's business capital. (Hasan, 2003)

Zakah for productive project should be given to mustahik as a working capital or as a source of income. Actually they are a certain procedures to distribute zakah for productive activities. The rule is stated in Act No.23/2011 about Zakah management, chapter V article 29. That is about conducting feasible study, deciding the type of productive business, giving guidance and counseling, controling and supervision, evaluating and making report.

So, it can be concluded that productive zakah is different from consumptive one. Consumptive zakah is given for fulfilling daily need while productive zakah is given to mustahik in order to make them independent businessmen and finally to be muzakki.

\section{$>$ Utilization of Productive Zakat}

The empowerment is the distribution of zakat accompanied by a target to change the condition of the recipient (more specifically to the poor and poor) and the condition of the mustahik category into the muzakki category. The term empowerment is defined as an effort to broaden the choice horizon for the community, with the potential utilization effort, the best utilization with satisfactory results. (Bariadi, 2005)

The term empowerment or empowerment comes from the word power (power or empowerment). Empowerment is often interpreted as the acquisition of strength and access to resources. (Prijono, 1996) Whereas according to (Shardlow, 1998) empowerment is focusing the discussion on the problem of how individuals or groups or communities try to control their own lives and seek to shape the future according to their wishes.

People who have the ability to empower themselves will be able to make changes in a better direction so that they will increase their level of prosperity.

There are many models or patterns of utilizing zakat funds. If grouped there are at least two models, namely productive models and consumptive models. The productive model is similar to the "hook" analogy, namely the use of stimulus in the form of a stimulus to develop the recipient's ability, one example is the provision of credit to Micro, Small and Medium Enterprises (MSMEs). While consumptive models such as "fish" are direct assistance that can be enjoyed by the recipient. This term of productive and consumptive is popularly used in the utilization of zakat funds (IMZ, 2012)

Distribution or utilization of zakat, according to the guidelines for implementing zakat in the DKI Jakarta BAZIS, is determined as follows:

$>$ Being educative, productive and economical so that recipients of zakat at a time do not need zakat anymore. Even expected to be a person who pays zakat.

$>$ For the poor, converts and Ibn Sabil, the distribution of zakat is focused on the person not on the legal institution that manages it. This policy is carried out so that the elements of education contained in the distribution of zakat are clearer and more pronounced.

$>$ For the amil, gharimin and sabilillah groups, the division is focused on the legal entity or the institution that carries out and conducts Islamic activities. (Bariadi, 2005)

Empowerment based on charity alms giving has broader goals not just material aspects but there are other objectives, as follows:

- Strengthen faith. Strengthening faith is the main foundation of the utilization of zakat, not only the development of economic aspects.

- Improve the quality of life that consists of economic aspects so that it comes out of the poverty trap. 
- Growing the spirit of entrepreneurship to be independent (Bariyah, 2012)

- The utilization of productive zakat is intended so that the zakat distributed to mustahik can be useful by means of funds provided by zakat institutions used for mustahik businesses.

\section{$>$ Working Capital}

Working capital is The whole fund spent during current income on certain accounting period to produce an income.. (Soeprihanto, 1997).

The working capital is defined as a flow asset minus direct obligation. Mainly, working capital is a part of company asset which funtions as a means at the time of debet or credit. (Suwartojo, 1978)

In Islamic view, the working capital is all valuable wealth in the eye of shara', where human activities get involved to develop it. (Mediawati, E). Islam defines the capital as mentioned in Quran :

"Beautified for people is the love of that which they desire - of women and sons, heaped-up sums of gold and silver, fine branded horses, and cattle and tilled land. That is the enjoyment of worldly life, but Allah has with Him the best return." (Q.S. Ali-Imran : [3]:14).

Rahman suggested (Rahman, 1995) that the word "the love of that which they desire" means capital. It is because gold and silver, fine branded horses, and cattle gold are mentioned (including other capitals). Meanwhile, the word "Beautified" indicates that the capital is so important for human.

There are some concepts about capital. First, Quantitative concept. The working capital is the whole of current asset as known as (gross working capital). Second, qualitative concept. The working capital is some of current assets that are used to finance the business and its liabilities are not interrupted. In another word, this working capital is an excess of current income which runs on current debt. So, it is called by net working capital. Third, functional concept. The working capital is viewed as its functions in order to raise business income. (Soeprihanto, 1997)

\section{$>$ Working capital elements.}

Working capital elements can be :

- Ready cash. The money that is kept in Bank. Every company or service company usually needs cash. Since it can be brought everywhere.

- Securities which can be converted easily. Capital investment regulation on securities allows the companies to use their excess fund or cash balance in order to raise fund from it. Trade credits. Trade credits appear since the company sells credits to enhance the trade volume. Credit sale can't quickly get cash. But, it causes credit. It will be paid due to the payment time. Trade stock is a stock that is usually in business operation. It is usually bought and sold without further process. Hence, it results the format changing of the goods. (Soeprihanto, 1997)

Suwartoto, (Suwartojo, 1978) claims that working elements capital are:

- Bank cash.

- Securities.

- Easily billed receipts

- First expenses.

- Trade credits.

- Stock: Such as: raw materials, half-done materials and Finished-goods.

\section{$>$ Micro, small and medium enterprises}

Business is a unit of economy that runs an activity to produce goods or service in order to sell or change with other goods. In this case, there is one or more people who are in charge and having an authority to run that business. Authority may comprise staffing, marketing, financing and soon. In business concept, it can conclude all supporting units or assisting units which are located separately from their main office.(BPS, 2014)

Entrepreneurship is an independent business sector which usually exists to support national economy in any conditions. It will be more potential if supported by sufficient capital assistants. Thus, it needs a business capital from zahah agency which practices no usury. (Bariadi, 2005)

Enterpreneurship is all businesses which have certain positive aspect to modify old products into new ones. This process involves job opportunities. Besides, entrepreneurship means a smart or talented person who recognizes a new product, creates, markets and controls capital operation.(Bariadi, 2005)

There are some agencies or institutions who define micro, small and medium enterprises. Accoding to Act No. 20/2008, article 6 defines:

$>$ The micro enterprises criteria are:

- Possess net wealth about Rp50,000,000.00 not included the land and business infrastructure or

- Possess annual sales product at least Rp300,000,000.00

$>$ The small enterprisess criteria are:

- Possess net wealth more than Rp50,000,000.00 to Rp500,000,000.00 not icluded the land and business infrastructure or

- Possess annual sales product more than Rp300,000,000.00 up to Rp2,500,000,000,00

$>$ The medium enterprises criteria are:

- Possess net wealth more than Rp500,000,000.00 to Rp10,000,000,000,00 not included the land and business infrastucture, or

- Possess annual sales product more than Rp2,500,000,000.00 to at leas Rp50,000,000,000,00 
According to Act No.9/ 1995 Articlel. 5), The micro, small and medium enterprises are: a business activity which some criteria:

- Posess net wealth at least Rp.200,000,000.00 (dua ratus juta rupiah) not included land and businss infrastructure.

- Posess annual sales product at least Rp 1,000,000,000,00 (one miliar rupiah).

- Indonesian citizen

- Being independent, means not to be subsidiary company or branch company, or branch company which is owned or affiliated, directly or not to medium or big company.

- Established by individual or business unit. Unlegalized, or legalized business unit including cooperation.

The micro, small and medium enterprises are income sources for Indonesian country. A state can be assumed developed if there are minimum $2 \%$ business people. Based on the data and criteria arranged by Central Statistical bereau (BPS), The entrepreneurs by january 2012 were $1.56 \%$. Indonesia is really lack of businessmen. This causes Indonesia is only the market of foreign products. Thus, the condition will trigger a problem if Indonesian people don't get involved in business activities since 2016 was the era of free ASEAN market.

Nowadays, The poverty is still a big problem in Indonesia. The number of poor people in Indonesia is 28.28 million or $11,46 \%$ (BPS, 2014). The poverty issue is closely related to the human resource. The haves not will be difficult to fulfill their daily need. Education also plays an important role in developing people's condition. The lack of education creates stupidity and ignorance which make people difficult to get job opportunities. Zakah, infaq and shadaqa utilization can be a solution for this problem in the form of productive zakah. According to (IMZ, 2010) some of the mustahik are in productive age. They should be assisted by productive zakah program to get them out of the poverty. The system can be as a qardu al-hasan, mudharabah, murabahah, or other loan systems.

The Micro, small and medium sectors are really tough business during national economic crisis. Nowadays, $99 \%$ business people are running micro, small and medium enterprises. They will significantly grow and be able to support the national economic stability. The government has given empowerment efforts, such as: programs and activities. But, These effort don't give the right impact on business people and common society.(Hamid, 2010)

The micro, small and medium enterprises (MSME) in Indonesia still face a lot of problems. The problems are internal and external. These problems should be overcomed soon to achieve the maximum results : (1) The internal problem is the lack of capital and management.(2) The external factor, the problems come from the developer and supervisor. Such as: unproper given solution, no program monitoring and overlapping program among several institutions. (Hamid E. S., 2010)
Economic development is an important agenda for every country. This program is aimed to improve social welfare. MSME are able to take the action in this development. MSME play important roles in this development because they are able to employ unskilled labors in traditional and modern small business. (Wulansari, 2014)

It can be concluded from previous study that productive zakah that is given to MSME, really gives great impacts on mustahik life.

\section{DATA ANALYSIS}

Based on previous data, at least there are 100 zakah Management Agencies (ZMA) from $180 \mathrm{ZMA}$ or about $44.44 \%$ which practice the productive zakah pattern. It means that there are many zakah management agencies think this kind of zakah pattern is effective to get the haves not out of the poverty. Productive zakah can be classified into traditional pattern and creative one.

Yayasan Dana Sosial al-Falah (YDSF). This foundation practices Program desa mandiri (Independent village program) and program ekonomi desa (Village economy program). In November 2011, MSME program accepted 51 new members with assisted capital about Rp 74,835,000 di Magetan and Bojonegoro to develop city and village economy. Zakah mangement agency is responsible to develop moslem's standar of living. This foundation lent $\mathrm{Rp} 13,000,000.00$ for 13 MSME entrepreneurs.. (YDSF, 2011)

> Muamalat Baitulmaal. There are several Economy empowerment programs in Muamalat Baitulmaal. First, BMT Shar-e (Micro institution in Bank Muamalat network). The collaboration between Muamalat Baitulmaal and Baitul Maal wa Tamwil produces BMT Shar-e program. Muamalat Baitulmaal is trusted to manage Sharia Micro finance institution that is initiated by Bank Muamalat Indonesia together with PINBUK and the society for BMT Shar-e program. This program was started in 2010 without government funds.

This program is (linkage program) between Muamalat Baitulmaal and Baitul Maal wa Tamwil (BMT) in all partership areas. The collected funds of this program are distributed in the form of small business financing. The number of this program are $222 \mathrm{BMT}$ in 10 provinces in Indonesia.

Second, Sharia on-going fund.This program is a kind of cooperation between the ministry of cooperation and MSME and Bank Muamalat. Muamalat Baitulmaal provides assistance, couching, monitoring and evaluating. This Program is provided for small and medium cooperation. This assistance was done in 2003- 2007. 
DBS (Dana bergulir Syariah) ( Sharia progressing fund) can also be utilized to strengthen the role and position of KJKS/UJKS (Koperasi Jasa Keuangan Syariah/Unit Jasa Keuangan Syariah) (Sharia finance service cooperation and Sharia finance service unit) as an instument for microbusiness empowerment. The number of portfolio of DBS (Sharia progressing Fund) are around Rp.136,1 billion, with 144,734 members. 1,306 KJKS or UJKS, in 33 provinces / 273 districts.

Third, Kampung Jamur Ciputih (Ciputih mushrooms village). This (village) is under BMM supervision which is able to produce $1,371.3 \mathrm{~kg} /$ mushroom a year. The table below shows the product of the groups of Kampung Jamur Ciputih program:

\begin{tabular}{|c|c|c|c|}
\hline $\begin{array}{c}\text { Groups' } \\
\text { Name }\end{array}$ & Member & $\begin{array}{c}\text { Baglog } \\
\text { Production }\end{array}$ & $\begin{array}{c}\text { mushrooms } \\
\text { cultivation }\end{array}$ \\
\hline Mawar & 4 & 5,465 & $191,1 \mathrm{~kg} / \mathrm{month}$ \\
\hline Melati & 4 & 5,684 & $359,5 \mathrm{~kg} / \mathrm{month}$ \\
\hline Anggrek & 4 & 4,891 & $321,9 \mathrm{~kg} / \mathrm{month}$ \\
\hline $\begin{array}{c}\text { Wijaya } \\
\text { Kusuma }\end{array}$ & 4 & 5,400 & $59,85 \mathrm{~kg} / \mathrm{month}$ \\
\hline Pemuda & 5 & 740 & $3,65 \mathrm{~kg} /$ month \\
\hline
\end{tabular}

Table 1

Fourth, KUM3 (Komunitas Usaha Mikro Muamalat berbasis Masjid) or Muamalat micro business community with The mosque basis. Since it is operated, KUM3 has assisted 1,060 micro business groups with total 8,908 mustahik which are scattered in 20 provinces in Indonesia.

The summary Program f KUM3 in 2013 recorded 990 mustahik, 22 guides, 42 mosques from 20 provinces, 198 groups with the distributed capital around Rp.2,07 billion.

The total number of KUM3 members from 2006 to 2013 are 8,913 mustahik, 207 guides, 306 mosque from 20 provinces, 821 goups with the total distributed capital about Rp.9,17 billion. (Baitulmaal Muamalat, 2014)

Rumah Zakat (The house of zakah). This house of zakah provides lots of productive programs. Such as: providing business capital, in form of cash or cattle.

- Entrepreneurship support is a Program to enhance micro and small businesses under The house of zakah supervision. The support or assistance can be in the form of capital or infrastructures. The capital is given after the feasible assessment result. The donation is about Rp. 17,700,000. For 1 PM per year.

- Goat Breeding is a kind of society economy empowerment in livestock sector with the scheme of breeding around Rp. 57,000,000,- for 4 stock farmers in one year supervision. (every stock farmer gets 5 goats). Goat Fattening is a kind of society economy empowerment by giving the stock farmers some goats in the scheme of fattening in the colony system in The house of zakah stall. The value of donation is $\mathrm{Rp}$. $102,000,000,-$ for 6 people for 4 supervision's month. Everyone gets 10 goats. Cow Fattening is a kind of society economy empowerment by giving the stock farmers some cows in the scheme of fattening in the colony system in the house of zakah house stall. The value of donation is Rp. 133,000,000 for one stock farmer for 4 months' supervision. Every stock farmer gets 10 cows.(Rumah Zakat, 2016)

Dompet Dhuafa conducts a lot of economy programs, they are:

- Live stock. (cattle charity). This program has been accomplished for more than 9 years. This program is the cattle basis program for the haves not. Since 2002 , at least 1449 received this cattle program, This program produced 5745 goats and 222 cows. The stock farmers get the guidance since the breeding process, feeding, technology assistance, management and veterinarian. This program has spread in 5 provinces and 10 districts in Indonesia.

- Agriculture. Pertanian Sehat Indonesia (PSI) or Indonesian Health Agriculture from Dompet Dhuafa has been founded on june 1999. This program formerly was Laboratorium Pengendalian Biologi ( Biological controlling Lab )DD Republika which functions to search and develop agricultural infrastructure for the poor farmers.

Biopestisida is the first product from Biological controlling Lab of Dompet Dhuafa Republika. It is a kind of pest control containing an active insect virus NPV (nuclear polyhedrosis virus) that is environmental friendly. This Biopestisida is firstly produced using the name VIRL, VIR-X dan VIR-H. The later research and technology assembly in 2000 produced organic fertilizer OFER and vegetable pesticide PASTI containing active substance of tuba root extract (Derris sp.).

In 2002 Biological controlling Lab changed into Health agriculture unit. It is related to all product marketing development from previous Lab. The laboratorium division from business activity is done by early 2003 that turns into LPS that is located under Social aset net (Jejaring Aset Sosial ) (JAS) dan Sharia Banking Unit (UPS) which is posited under Jejaring Aset Reform (JAR) (Reform asset net). Beside product laboratorium, UPS also starts to market agricultural product to the farmers. Such as: Beras Sehat Bebas Pestisida. (Health free pesticide rice).

In early 2004 Pertanian Sehat Indonesia (PSI) or Indonesia health agriculture and Usaha Pertanian Sehat (health agriculture business are joined together to be Lembaga Pertanian Sehat Dompet Dhuafa (Health agriculture agency) Dompet Dhuafa which is posited under coordination Jejaring Aset Reform (JAR) ( Reform Asset networ). This agency has a greater mandate not only to produce and investigate the infrastructure of health agriculture, but also try to empower the poor farmers through Program Pemberdayaan Pertanian Sehat (P3S) or Health Agricultural empowerment program. In 2005 , LPS became one of the economy development network that is assumed financially independent from product and business sector. 
- MSME and creative industry. In order to end the poverty circle, since 2000 Dompet Dhuafa has interracted with many villages'communities, in cities and several areas after the natural disaster. DD built community empowerment programs based on economic cluster. Many programs are held in order to help people solve their social problems. This program is spreading all over Indonesia.

- LKMS (Lembaga Keuangan Mikro Sayriah) or Sharia micro finance Agency has two major programs. First, Social Trust Fund. Bank is of one of financial source used by modern people. Since the bank firstly runs its business for profit oriented, it is very careful in choosing its clients to keep the security and continuousness. The bank always chooses the potential clients who are able to pay their debt or loan and able to contribute the profit for it. Hence, the bank issues a lot of strict requirements to get the loan. Only the haves can afford them while The haves not can afford them because they don't have any business and bail. As the result, the haves not avoid the bank.

Overcoming this problem, many banks are created for the haves not. They are: Bank Perkreditan Rakyat (Rural Banks), Koperasi Simpan Pinjam (saving and loan cooperation) and lembaga keuangan mikro (Micro Financial Institution). The practice of Grameen Bank (from Bangladesh) which is assumed suitable for the haves not, is widely adopted inIndonesia. In Sharia financial Institution term, Baitul Mal wa Tamwil (BMT) is also practiced to help the haves not that is posited later on under sponsorship of Jasa Keuangan Syariah (KJKS) or Sharia financial service.

But, many of these non profit financial institutions are gradually leave their noble orientation and again use their profit oriented system. In fact, Some of them put the social aspect in their financial structure with minimum scheme. The ratio is not more than $5 \%$. It denotes that they are not really want to help the weak people. On the contrary, the haves not need the financial institutions who can help them sincerely. In this case, saving and loan practice can be a pure social financial transaction. Here, the function of akad Dana Kebajikan (Qardhul Hasan: or borrowing money and retur it back without additional fee) is very dominant. This kind of financial practice is really needed by people to run their businesses after the natural disaster.

$>$ Pos Kemanusiaan Peduli Ummat (PKPU) or Humanitarian Care Caring For The Ummah conducts several economic programs. They are:

- Eating Cart. Gerobak Makan. The program is to give the haves not the loan to run and develop their business. Besides the money, they also get the assistance to develop their business. The survey is also conducted for the feasible loan clients. The assistance and guidance are done in two weeks to see the business progress.

- KUMM (Kelompok Usaha Mandiri Masyarakat) or Community Independent Business Groups. They are groups of people who agree to do social and economic activities on democracy, participatory, honesty and equity principles. This program is aimed to develop the standars of living of every member by improving his /her daily incomes. This program also involves intensive guidance and assistance.

- Warung Kaget(Sudden stall). This program is conducted for people who just escaped from the natural disaster. This program is hopefully help the victims recover and start their new business. The objectives of this program are to

Grow the spirit of the victims, strengthen their independence, guide, assist, support, and develop their abilities and skills to do their new business. (PKPU, 2015)

BAZNAS. (National Zakah Board). This institution practices in the form of Baitul Qiradh BAZNAS (BQB) atau Rumah Makmur (prosperous house). BAZNAS has the vision. They are: Being sharia micro financilal institution in order to enhance the continous value-added mustahik micro business.

MISSIONI: To educate and improve the competency mustahik entrepreneurship or (Entrepeneurship Development Program), mustahik incomes in order to fulfill his or her essential needs independently, to make them muzakki.

Baitul Qiradh BAZNAS or Rumah Makmur (prosperous house) BAZNAS is a kind of sharia micro financial institution which owns cooperation legal entity. This institution distributes ZIS funds productively through soft loan (Al Qardhul Hasan) or financing project using sharia scheme for the mustahik.

The use of Qardh al-hasan contract ( akad qardhul hasan) for zakah distribution is allowed for two reasons: First, to train mustahik mental and responsibility to utilize the loan for their business development. Second, the returned load can be turned to other mustahik to run their business or as the deposits for the mustahik in sharia cooperation. So, the returned loan will be in the right person. The objectives of BMT founding is to keep the liquidity needed to develop mustahik business.

There are some productive ecomomic activities as reported by BAZNAS on December 30, 2015. BAZNAS at Sragen district, in central java province, donated the working capital fund to 49 mustahik. BAZNAS also donated for productive economy support. Every registered mustahik got Rp 1,000,000.00 and the mustahik who joined productive economy program got Rp 2,000,000.00 . the donation fund was kept in Koperasi Jasa Keuangan Syari'ah Lembaga Ekonomi Syari'ah Badan Amil Zakat (KJKS LES-BAZ), and can be withdrew anytime. (BAZNAS, 2016)

Dompet Peduli Ummat Daarut Tauhid (DPU DT). Di DPU Daarut Tauhid Program Ikhtiar KU is a kind of productive program. It is design to empower people to be economically independent using their own skills and potentials. For these objectives, DPU Daarut Tauhiid creates several economic programs. They are: 
Economic independent program DPU Daarut Tauhiid which distributes zakah in the form of working capital. That is Misykat program (Microfinance Syariah Berbasis Masyarakat). This program is productive zakah utilization that is managed sistematically, intensively and cotinously. The mustahik is given ongoing fund, skill, entrepreneurship concept, saving education, potential exploration, character building so they are competent and independent.(DPU DT, 2016)

Those institutions are the ones who practiced productive zakah for mustahik working capital.This kind of zakah utilization should be developed and practiced in order to realized the real meaning of zakah itself. zakah is not only contains its function as the worship to God but also as society fund. (Ali, 1998)

Zakah contains social-eonomy aspect and spiritual one.

From Social-ekonomi aspect, zakah is able to support the haves not economic growth by improving their purchasing power (consumptive aspect). Besides, zakah also provides more job opportunities and incomes for the haves not by giving working capital. From spiritual aspect, zakah is one of Islamic pillar which is able to free human from any kinds of exploitaion. Such as: slavery, extortion, social and economc exploitation based on the worship to Allah. (Umar, 2008)

Both aspects of zakat benefits above appear to be reflected in the implications felt by weak communities through productive utilization programs, as implemented by the above zakat institutions such as the al-Falah Social Fund Foundation (YDSF), Baitulmaal Muamalat (BMM), Zakat Houses, Wallets Dhuafa (DD), Post of Humanitarian Care for Ummat (PKPU), National Zakat Agency (BAZNAS), Dompet Peduli Ummat Daarut Tauhid (DPU DT).

Beside the previous two aspects, the target of giving working capital to mustahik is to escape them from the vicious circle that causes the poverty. Also, To escape them from The loan sharks who lend the money with high interest. More over, working capital can support them to be optimistic in living and escape them from debt bondage.

The application of productive zakah is actually based on social benefit that are both accepted theoretically and practically in social life. If we see the verses which are talking about zakah, we can see that the productive zakah provision can be put in orders. They are:

- Al-Quran generally explains that zakah should be distributed to 8 groups of people. But, there is no specific description on how to utilize it. It means that Al-Quran give free choice to utilize.

- There is an example from the prophet ( PBUH) that zakah can be productively used because it can maximize zakah function to develop the haves not economy.

- There is an example from sahabah (prophet companions) practices. zakah can support the haves not living cost. This practice is based on al-maslaha (social benefit).

- Some of fuqaha (fiqh experts) have some suggestions to practice the productive zakah pattern.

- Contemporer Islamic philosopher suggested productive zakah.

- Based on social-economy and religious aspect, productive zakah can get the haves not out of continously poverty. (Umar, 2008)

- The success stories from any zakah management agencies show that this kind of zakah is able to overcome the poverty and turn the mustahik to be the muzakki.

\section{CONCLUSION AND RECOMMENDATION}

\section{A. Conclusion \\ Based on previous study, it can be concluded that :}

Zakah management agency is an alternative agent to overcome the poverty problem by giving the working capital for MSME.

> Zakah Management Agencies implement the productive zakah pattern in order to help the mustahik be economically independent and make them muzakki in the future.

$>$ Productive zakah distribution for MSME is an effective way to get the mustahik out from the poverty.

\section{B. Recommendation}

$>$ The researchers are to find out further about income data after the mustahik got the woking capital from zakah management agency.

$>$ It is urgent for zakah management agencies to socialize the productive zakah program. Especially, in the remote areas. Where many of them are still illiterate and trapped by usury practices.

\section{REFERENCES}

[1]. Ali, M. D. 1998. Sistem Ekonomi Islam Zakat dan Wakaf. UIP.

[2]. arikunto, s. 2006. prosedur penelitian suatu pendekatan praktik. Jakarta: PT. Rineka cipta.

[3]. Muamalat Baitulmaal. 2014. Program Pemberdayaan Ekonomi BMM. Interpreted again from Muamalat Baitulmaal: http://www.baitulmaalmuamalat.org/

[4]. Bariadi, L. Z. 2005. Zakat dan Wirausaha. Jakarta: CED (Centre for Entrepreneurship Development).

[5]. Bariyah, N. O. 2012. Total Quality MAnageent Zakat, Prinsip dan Praktik Pemberdayaan Ekonomi. Wahana Kardofa FAI UMJ.

[6]. BAZNAS. 2016. Badan Amil Zakat Nasional. Interpreted again from Program Ekonomi BAZNAS: http://pusat.baznas.go.id/rumah-makmur-baznas/

[7]. Beik, I. S. 2009. Analisis peran zakat dalam mengurangi kemiskinan. Zakat \& Empowering Jurnsl Pemikiran dan Gagasan, Vol II.

[8]. BPS.2014.Diambilkembali dari Data Statistik BPS:http://www.bps.go.id/Subjek/view/id/35\#subjek ViewTab1|accordion-daftar-subjek2 
[9]. Dompet Dhuafa. 2015. Program Ekonomi. Interpreted again from Program Ekonomi Dompet Dhuafa: http://www.dompetdhuafa.org/ekonomi/

[10]. DPU DT. 2016. Program Ikhtiar Ku DPU DT. Interpreted again from Dompet Peduli Ummat Daarut Tauhid: https://dpu-daaruttauhiid.org/web/program/2

[11]. Hafidhuddin, d. 2002. Zakat dalam Perekonomian Modern. Jakarta: Gema Insani Press.

[12]. Hamid,E.S. 2010. Pengembangan UMKM untuk Meningkatkan Pertumbuhan Ekonomi Daerah. Simposium Nasional, 2.

[13]. Hasan, M. A. 2003. Masail fiqhiyah Zakat, Pajak, Asuransi dan Lembaga Keuangan. Jakarta: PT Rajagrafindo Persada.

[14]. Helliana, e. a. 2012. Membangun Kepercayaan Konsumen : Faktor Penting pada Lembaga Amil Zakat Seluruh Indonesia. Prosiding Seminar Nasional Penelitian dan PKM, 127.

[15]. IMZ. 2010. Menggagas Arsitektur Zakat Indonesia : Menuju Sinergi Pemerintah dan Masyarakat Sipil dalam Pengelolaan Zakat Nasioanal. Jakarta: IMZ.

[16]. IMZ. 2012. Membangun Peradaban Zakat Indonesia : Soal Kebijakan dan Hal Lain yang belum Paripurna. Jakarta: IMZ.

[17]. Mediawati, E. t.thn.. Konsep Utang dan Modal dalam Islam.

[18]. PKPU. 2015. Program Ekonomi PKPU. Interpreted again from PKPU: http://www.pkpu.org/program/ekonomi/

[19]. Prijono, O. S. 1996. Pemberdayaan : Konsep, Kebijakan, dan Implementasi. Jakarta: CSIS.

[20]. Rahman, A. 1995. Doktrin Ekonomi Islam 1. Yogyakarta: PT. Dana Bhakti Wakaf.

[21]. Rumah Zakat. 2016. Program Senyum Mandiri. Interpreted again from Program Senyum Mandiri Rumah Zakat: https://www.rumahzakat.org/program/senyummandiri/

[22]. Rusli, H. A. 2013. Analisis Dampak Pemberian Modal Zakat Produktif Terhadap Pengentasan Kemiskinan Di Kabupaten Aceh Utara. Jurnal Ilmu Ekonomi, 3.

[23]. Soeprihanto, J. 1997. Manajemen Modal Kerja. Yogyakarta: BPFE-Yogyakarta.

[24]. Suwartojo, B. 1978. Modal Kerja. Jakarta: Balai Aksara.

[25]. Umar, M. 2008. Pendayagunaan Zakat untuk Usaha Produktif. Jambi: Sulthan Thaha Press.

[26]. Undang-undang Republik Indonesia Nomor 23 Tahun 2011 tentang pengelolaan zakat. t.thn..

[27]. Wulansari, S. D. 2014. Analisis Peranan Dana Zakat Produktif Terhadap Perkembangan Usaha Mikro Mustahik. Diponegoro Journal of Economics, 1.

[28]. YDSF. 2011. YDSF. Interpreted again from Program Yayasan Dana Sosial al-Falah: http://www.ydsf.org/program 